\title{
Romantic Relationships in Emerging Adulthood: Perception-Partner Ideal Discrepancies, Attributions, and Expectations
}

\author{
Georgia Stephanou \\ Department of Early Childhood Education, University of Western Macedonia, Florina, Greece \\ Email: gstephanou@uowm.gr, egokesy1@otenet.gr
}

Received October 17 $7^{\text {th }}, 2011$; revised November $19^{\text {th }}, 2011$; accepted December $16^{\text {th }}, 2011$

\begin{abstract}
This study aimed to examine 1) emerging adults' attributions for their subjectively perceived current romantic relationship as good or bad; 2) the role of their perception-partner ideal discrepancies in estimating their current romantic relationship as good or bad, and in the formation of attributions; and 3) the effects of all the three concepts on the generation of the expectations for the quality of the romantic relationship in the future. Undergraduate and postgraduate university students, from various faculties, ages of 18 to 25 , both genders, participated in this study. The participants filled in, first, the scale of the romantic partner ideals, and, after one week, the scales of perceived of the quality of the current romantic relationship, attributions and expectations. The results regarding attributions revealed that 1) the perceived good romantic relationships were mainly attributed to internal and self-partner internal and controllable factors (love, passion, effective communication, honesty-loyalty, understanding each-other), whereas the perceived bad romantic relationships were mainly attributed to personal uncontrollable, external, unstable and partner's internal factors (untrustworthiness, lack of passion, non honesty-loyalty, lack of love, and ineffective communication); and 2) locus of causality, followed by personal controllability and stability, was the most powerful attributional dimension in discriminating the two groups of the emerging adults. The findings regarding the perception-partner ideal discrepancy showed that 1) the students who had smaller perception-partner ideal discrepancy, compared to students who had larger perception-partner ideal discrepancy, estimated their current romantic relationships more favourable but only trustworthiness accounted for unique variance in it; and 2) perception-partner ideal discrepancy in trustworthiness, followed by warmth/intimacy, and attractiveness/vitality, was the most powerful factor in discriminating the two groups of the participants. The results with respect to effects of partner ideal discrepancy on attributions indicated that 1) the students' perception-partner ideal discrepancies proved to be a significant and positive factor in the formulation of the attributional dimensions (expect for external controllability), mainly both stability and locus of causality, for the perceived current quality of their romantic relationship; and 2) only trustworthiness and warmth/intimacy had unique effects on locus of causality, and only trustworthiness uniquely contributed into stability, partner's locus of causality, and self-partner interactive locus of causality. Finally, the three concepts, as a group, positively influenced the generation of expectations of the quality of the romantic relationship in the future but no one of the components of the perception-partner ideal discrepancy was unique contributor, while stability, self-partner interactive controllability, and, particularly, the perceived quality of the relationship accounted for unique variance in relationship expectations.
\end{abstract}

Keywords: Attributions; Emerging Adulthood; Expectations; Perception-Partner Ideal Discrepancy; Romantic Relationship

\section{Introduction}

Attaining love and romance ensures happiness and longevity and contributes to satisfy the need for positive long-term social bonds (Berscheid \& Ammazzalorso, 2003; Carr, 2005; Fehr, 2003; Forgas \& Smith, 2005; Hendrick \& Hendrick, 2005; Rusbult, Arriaga, \& Agnew, 2003). On the other hand, forming and maintaining a successful romantic relationship is a challenge as well as finding a desirable partner or any partner at all may be confronted with difficulties (Clark \& Beck, 2010; Rusbult et al., 2003). Also, even finding a desirable partner, the things can go wrong, and happiness may disappear (Maner \& Miler, 2010). These topics are particularly troublesome among emerging adults due to the fact that, among others, they have little experience with forming and maintaining a successful long-term relationship (Arnett, 2000; Fincham \& Cui, 2010; Clark \& Beck, 2010; Maner \& Miler, 2010; Stanley, Rhoades, $\&$ Fincham, 2010).

Emerging adulthood has been defined as a specific stage of life between the ages of 18 and 25, during which individuals are neither adolescents nor adults with full responsibility for themselves and for others, and during which they evaluate possible romantic relationships, estimate world views, and seek and are preparing for future careers (Arnett, 2000, 2004; Collins \& Sroufe, 1999). Indeed, this is a distinct stage of life, characterizing "by the process of initiating goal pursuits and deliberating about goals regarding partners, world views, and work" (Clark 
\& Beck, 2010: p. 190). However, as Clark and Beck (2010) emphasize, little literature has been devoted to "the intra- and interpersonal psychological processes involved in the tasks of this period" (p. 190), while it has been mainly related to age, tasks, and a lack of commitments.

While romantic love is a complex phenomenon, there is a remarkable increasing research shift in defining and explaining it (Fletcher, 2002; Fitness, Fletcher, \& Overall, 2005). Romantic love has been conceptualized as attachment, caregiving and sexual attraction, and it is crucial in the development of intimate relationships (see Adams, 1986; Fitness et al., 2005; Shaver, Morgan, \& Wu, 1996).

Cognition and cognitive process are significant contributors in the development and quality of a romantic relationship (Harvey, Pauwels, \& Zickmund, 2005; Karney, McNulty, \& Bradbury, 2003). Intuitive and atributional appraisals are two such constructs, which are main concepts in Weiner's (1992, 2001, 2005) attribution theory, and, which have been central concepts in the research in close relationships (Collins, Ford, Guichard, \& Allard, 2006; Connelly \& McIsaac, 2009; Fincham, 2003; Greitemeyer \& Weiner, 2003; Harvey, 1987; Harvey \& Omarzu, 1999; Prager, 1995; Reis \& Patrick, 1996; Stephanou, 2005, in press; Weiner, 2000). Whether partners perceive their relationship as good or bad, and which explanations or interpretations they make about the relationship influence their emotions, motivation and behaviour (Blascovich \& Mandess, 2000; Flecher, Fitness, \& Blampied, 1990; Flecher \& Thomas, 2000; Fincham, 2003; Fincham, Beach, Arias, \& Brody, 1998; Fitness et al., 2005). Specifically, the belief that a person has about the causes of his/her romantic relationship influences his/her feelings for the partner, and his/her expectations for the quality of the romantic relationship in the future (Clark, Fitness, \& Brissette, 2003; Fletcher, 2002; Siemer, Mauss, \& Gross, 2007; Weiner, 2001). Then, emotions and expectations influence the individual's actual behavior toward the partner, and the romantic relationship itself (see Fincham, 2003; Fletcher \& Thomas, 2000; Weiner, 2001). For example, as Fletcher and Thomas (2000) found in their longitudinal study, spouses' conflict-promoting attributions for marital problems were related to more negative interaction behavior during a 12month period. Contrarily, by attributing successful relationship/partners' success to internal factors the individuals sustain their positive view about the relationship/partner, experience positive emotions, have higher motivation and persistence, and exhibit positive interaction behavior in the future (Murray, Holmes, \& Griffin, 1996b; Steele, 1988; Stephanou \& Kyridis, 2011; Taylor, 1989).

One the other hand, people has beliefs and ideal standards about romantic partners and relationships through which they cognitively evaluate their partners and relationships (Higgins, 1987, 1989; Regan, 1998; Rusbult, Onizuka, \& Lipkus, 1993; Rusbult et al., 2003). More precisely, individuals have certain beliefs about the content and meaning of love, and the factors that cause relationship to fail or succeed (Fehr, 1999, 2003; Fletcher \& Kininmonth, 1992). For example, partners know whether they are in a good relationship by comparing their perceptions of their current relationship with their pre-existing ideals about a good relationship, and the more congruent the fit, the happier they are (for a review see Simpson, Fletcher, \& Campbell, 2003). Furthermore, according to Simpson et al.'s (2003) ideals standard model in close relationships, which was originally developed by Fletcher, Simpson, Thomas, and Giles (1999), the relationship-based knowledge involve the components of the self, the partner, and the relationship that are likely to overlap, and have the functions of evaluation, explanation, and regulation. The partner and relationship ideals, in particular, "operate as chronically accessible knowledge structures that probably predate - and may casually influenceimportant judgments" (Simpson et al., 2003: p. 89), such as the perceived causes of relationship success (Fletcher \& Kininmonth, 1992) and what is a "good" relationship (Hassebrauck, 1997), and decisions in relationships (see Fletcher et al., 1999).

People also have expectations about the partner, the relationship and the self in general that are based on previous experience, and influence their judgments, emotions and behavior in the current romantic relationship (Simpson et al., 2003; Simpson \& Rhodes, 1998; Stephanou \& Kyridis, 2011). These expectations are partly constructed through the cognitive appraisals the partners make in the relationship (Forgas \& Smith, 2005; Trope \& Gaunt, 2005). Furthermore, the dispositional attributions an individual makes to the partner reflect expectations of how he/she will behave in various situations (see Berscheid \& Ammazzalorso, 2003; Karney et al., 2003; Trope \& Gaunt, 2005).

However, relatively little research has focused on the interpersonal psychological processes involved in romantic relationships in emerging adulthood (Clark \& Beck, 2010; Field, Diego, Pelaez, Deeds, \& Delgado, 2010; Fincham \& Cui, 2010; Stanley et al., 2010). Specifically, little research has examined the association of emerging adults' perception-partner ideal discrepancies with their perceptions and attributions for their current romantic relationship, and relationship expectations (see Fincham \& Cui, 2010; Rusbul et al., 2003; Stephanou \& Kyridis, 2011).

This study, aiming to fill a research gap, focused on perception partner-ideal discrepancy, attributions and expectations in romantic relationships in emerging adult university students. This study was mainly based on Weiner's attribution theory, and on Simpson et al.'s (2003) ideals standard model in close relationships.

\section{Romantic Relationship Appraisals and Expectation}

People appraise a relationship by evaluating and by attributeing causes (Leary, 2000; Smith \& Lazarus, 1990; Trope \& Gaunt, 2005). The appraisals reflect what the stimulus-relationship means to them and whether it is good or bad (Fincham, 2003; Fitness et al., 2005).

People spontaneously attribute causes by the way they talk and think about their relationships (Fletcher \& Fincham, 1991). Although, an intimate interpersonal relationship could be attributed to infinite number of attributions, self, other person, situation, environment, self-other person interaction, and relationship itself are the most prominent causes in describing positive and negative relationships (Argyle, 2001; Erber \& Gilmour, 1995; Planalp \& Rivers, 1996). However, the content of causes is not the crucial, as the location of the causes on attributional dimensions. Specifically, attributions are categorized into causal dimensions of locus of causality (internal/external to the person), stability (stable/unstable over time) and controllability (personal and external controllable/uncontrollable), which have psychological and behavioral consequences (Argyle, 2001; 
Berscheid \& Ammazzalorso, 2003; Fletcher \& Thomas, 2000; McAuley, Duncan, \& Russell, 1992; Stephanou, 2007, in press; Weiner, 2002, 2005).

Previous researches indicate that the perceived quality of the relationship differentiates the attributional pattern (Fiedler, Semin, Finkenauer, \& Berkel, 1995; Fincham, 2003). For example, there is strong correlation between the positivity of causal attributions and relationship satisfaction (Fletcher \& Thomas, 2000). Furthermore, attributions maintain the preexisting relationship satisfaction regardless of the partner's behavior (see Fitness et al., 2005). Satisfied people with their relationships, tend to make charitable attributions for their partners negative behaviour as well as they make optimistic attributions for communication difficulties. Also, happy couples attribute their partners' positive behaviour to dispositional rather than situational factors, and they focus their disagreement on a specific issue, rather than globally criticise their partners (Carr, 2000; Gottman, 1993; Harvey et al., 2005). Yet, the longitudinal association appears to be mediated by the effects of attributions on efficacy expectations which, in turn, influence satisfaction (Fincham, Harold, \& Gano-Phillips, 2000). In contrast, the more negative the interpersonal relationship the more the attributions to the other person's constant negative properties (Argyle, 2001; Gilbert \& Malone, 1995; Hewstone \& Antaki, 2001).

Generally, individuals tend to attribute their good intimate relationships to themselves (internal, stable, personal controllable, and external uncontrollable), and their bad interpersonal relationships to the other person and situational factors (Fitness et al., 2005; Stephanou, 2005, 2007; Weiner, 1995, 2001, 2002; Ybarra \& Stephan, 1999).

Concerning the effects of attributions on relationship expectations, the literature documents that the nature of attributions significantly influences how the relationship satisfaction changes or remain constant over time (Bradbury \& Fincham, 1990; Harvey, 1987). For example, attributing successful romantic relationship to internal and stable factors enhances relationship expectations, and facilitates relationship engagement, while attributing negative romantic relationship to unstable is likely to improve the relationship and minimizes the feeling of hopelessness (see Fincham, 2003; Karney et al., 2003; Stephanou \& Kyridis, 2011). In contrast, attributing negative relationship to internal, and particularly, stable factors reduces positive expectations, produces the feeling of hopelessness and can lead to learned helplessness, a sense that none effort can lead to good romantic relationship (see Fitness et al., 2005; Peterson \& Steen, 2005; Seligman, 2002; Weiner, 2001). Also, partners who are satisfied with their relationships predict relationship longevity (see Fitness et al., 2005).

\section{Association of Perceived Partner-Ideal Discrepancy with Romantic Relationship Appraisals and Expectation}

According to Simpson et al.'s (2003) model of ideal standards model, the relationship and partner ideals have three functions: evaluation, explanation, and regulation. More precisely, a series of studies performed by Fletcher, Simpson and their colleague indicate that people compare their current partner or romantic relationship with their pre-existing standards and ideals about what is a good or a bad relationship or partner in order to estimate their partner or relationship as good or bad (see Flecher et al., 1999; Simpson et al., 2003). The finding is that the higher the matching, the happier they are with their relationships, and the higher the predictions of staying with their partners. In contrast, the larger actual-ideal discrepancies the more intense the dejection-related emotions, such as dissatisfaction, disappointment and shame, they experience, and the higher the changes of breaking up the relationship.

Individuals also use this comparison to explain and understand their relationship. For example, the partners by making attributions and giving causal accounts explain relationship satisfaction or problems (Fletcher \& Kininmonth, 1992; Hassebrauck, 1997). Furthermore, the perceived causes of a relationship success, compared to global relationship concepts like love, is more similar to ideal standards (Simpson et al., 2003).

The flexibility of ideal standards affects the three functions in the romantic relationship. For example, men and women exhibit more flexibility in evaluating short-term relationship than long-term relationship (Kenrick, Groth, Trost, \& Sadalla, 1993; Regan, 1998). It is reasonable to hypothesize that perception partner ideal discrepancy will account strongly in atributions about their long-term romantic relationships.

As above mentioned, the findings also document the ideal standards in close relationships comprise three interrelating components, the self, the partner, and the relationship (see Baldwin, 1992; Fletcher \& Thomas, 1996). Ideal partner and ideal relationship overlap, since individuals prefer ideal partners who could contribute in forming their ideal relationships (see Fletcher et al., 1999).

Previous researches (e.g., Campbell, Simpson, \& Orina, 1999; Gangestad \& Simpson, 2000) suggest that people judge ideal partner on three basic dimensions: Warmth/ trustworthiness (intimacy, warmth, trust, and loyalty), vitality/attractiveness (attractive, energetic, and healthy), and status/resources (social status and resources). Researches on mate selection and mating strategies support that the three dimensions are related to successful mating (Buss \& Schmit, 1993; Gangestad \& Simpson, 2000; Simpson \& Gangestad, 1992). For example, by focusing on intimacy and commitment, an individual may be more likely to acquire a cooperative and committed partner. The relationships ideals consist of two dimensions: intimacy/loyalty (intimacy, loyalty, stability-corresponding to partner intimacy dimension), and relationship passion (not clearly paralleling the partner other dimensions) (see Simpson et al., 2003). Little research has examined the content of ideal standards across various ages, while the list of the components does not end.

It could be hypothesized that holding high partner ideal standards for intimacy and trust may reflect a preference for relationship intimacy and commitment. In the case of confirmation of the preference, the relationship should be considered successful, and an optimistic attributional pattern will explain it, whereas, in the case of non confirmation of the preference, the relationship will probably be estimated as unsuccessful, and the attributional pattern may reflect self-serving (see Steele, 1988; Taylor, 1989).

\section{Aim and Hypotheses of the Study}

This study aimed to examine 1) university students' attributions for their subjectively perceived current romantic relationship as good or bad; 2) the role of the perception-partner ideal 
discrepancy in the estimation of the current romantic relationship as good or bad, and in the formulation of the attributions; and 3 ) the effects of the perception-partner ideal discrepancies, the perceived current quality of the romantic relationship, and the attributions for the romantic relationship on the formulation of the romantic relationship expectations.

The hypotheses of the study were the following:

The participants will attribute the perceived quality of their romantic relationships to various factors but among them partner, self, partner-self interaction and environment will be dominant (Hypothesis 1a). The perceived good or bad romantic relationship will be attributed to self- and others-related factors, respectively (Hypothesis 1b). Locus of causality will be the most powerful dimension in discriminating the group of students with the perceived good romantic relationships from the group of students with the perceived bad romantic relationships (Hypothesis 1c). The perception-partner ideal discrepancies will positively influence the perception of the quality of the current romantic relationship, and the subsequent attributions (mainly, stability) (Hypothesis 2a). While the perception-partner ideal discrepancy will be relevant to warmth, intimacy, trustworthiness, loyalty, and attractiveness and passion, their prevalence will differ in the formation of the perceived quality of the current romantic relationship and of the attributions (Hypothesis 2b). All the three sets of the concepts, the perception-partner ideal discrepancy, the perceived quality of the romantic relationship, and the attributions (mainly, stability), will account for unique variance in relationship expectations (Hypothesis 3).

\section{Method}

\section{Participants}

The participants in this study were 176 male and 210 female undergraduate and postgraduate students. Their age ranged from 18 to 25 years $(\mathrm{M}=21.30, \mathrm{SD}=2.93)$. They came from six Greek Universities, representing various Faculties of studies. The students had experienced 2 breakups on average, and the duration of their current romantic relationship ranged from six months to three and half years. Of the participants, 254 and 132 students perceived their current romantic relationship as positive and negative, respectively (see below).

\section{Measurements}

Perceived of the current romantic relationship good/ bad. Students' perceptions of the quality of their current romantic relationships were examined by responding to a sevenpoint four items scale (e.g., "How good is your romantic relationship?", "How much satisfied are you with your romantic relationship?"). Responses ranged from 1 = not at all to $7=$ very much. The consistency of the scale was based on previous relevant to the topic literature (see Fincham, 2003; Fletcher, 2002; Schumm, Paff-Bergen, Hatch, Obiorah, Copeland, Meens, \& Bagaighis, 1986; Stephanou, 2005, 2007 , in press).

The participants themselves defined their current romantic relationship as good or bad by filling in the romantic relationship scale twice. Specifically, they, first, filled it for the current quality of their romantic relationship, and, then, mentioned the lowest value in each item over which their romantic relation- ship would be good. The participants whom the mean score was lower than the indicated as good relationship formed the group of good romantic relationships, while those whom the mean score of their romantic relationships was equal or higher than the indicated one formed the group of bad romantic relationships. Cronbach's alphas were .88 and .79 for the positive and negative romantic relationship, respectively.

Attributions for the perceived positive and negative current romantic relationships. The students' attributions for their subjectively perceived good or bad current romantic relationships were examined via the modified Causal Dimension Scale II (CDSII, McAuley et al., 1992), which is a reliable and valid research instrument in examining attributions for intimate interpersonal relationships in Greek population (see Stephanou, 2005, 2007, in press; Stephanou \& Balkamou, submitted; see also Weiner, 2001, 2006). The individuals, first, wrote down the most important cause, which, according to their opinion, influenced the current quality of their current romantic relationship, then, indicated how much this cause contributed to the given romantic relationship, and, finally, classified that cause along the attributional dimensions of locus of causality, stability, personal controllability, external controllability, partner's locus of causality, partner's controllability, self-partner interacttive locus of causality, and self-partner interactive controllability. Each subscale consists of three items, ranging from 1 (e.g., not at all stable) to 9 (e.g., totally stable). Cronbach's alphas were .84 for locus of causality, .83 for stability, .80 for personal controllability, .77 for external controllability, .78 for friend's locus of causality, .76 for friend's controllability, .80 for selffriend interactive locus of causality, and .76 for self-friend interactive controllability.

The partner ideals. The perception-partner ideal discrepancy. The construction of the scale of the students' beliefs about the traits or characteristics of their ideal romantic partner was based on previous similar research (see Field et al., 2010; Fletcher et al., 1999; Higgins, 1989; Regan, 1998; Gangestad \& Simpson, 2000; Simpson et al., 2003), and on the findings from a pilot research. In the pilot study, university students, both genders, between the ages of 18 and 25 , were asked to list the traits or characteristics that, according to their opinion, describe their ideal romantic partner, and to indicate the extent of the importance of each of the traits/characteristics on a seven-point item (from $1=$ not at all important to $7=$ very important). The results showed that the students' beliefs about the ideal partner characteristics were mainly relevant to attractiveness/vitality, warmth/intimacy and trustworthiness. Attractiveness/vitality characteristics concerned the partner's attractiveness, energy and healthy. Trustworthiness referred to partner's trust, loyalty and long-term involvement. Warmth/intimacy consisted of characteristics relevant to closeness, support and emotional bonding. We created a list of attributes that describe ideal partner, which was used in the main study. Each attribute-item ranged from $1=$ not at all to $7=$ very much.

In the main study, the participants completed this list twice. Specifically, the students indicated, first, the extent to which their ideal partner matches each of the items of the attractiveness/vitality, warmth/intimacy and trustworthiness, and, then, the extent to which their current romantic partner matched each of them. In the case of the ideal partner, Cronbach's alphas were: $.82, .83$ and .85 for attractiveness/vitality, warmth/intimacy and trustworthiness, respectively. Cronbach's alphas were also found to be satisfactory with respect to current partner 
scale, ranging from .70 for attractiveness/vitality thought .72 for warmth/intimacy to .79 for trustworthiness.

The perception-partner ideal discrepancy is the magnitude of the differences between current partner and ideal partner in attractiveness/vitality, warmth/intimacy, and trustworthiness.

Romantic relationship expectations. Partners' romantic relationship expectations were examined via the scale of the current romantic relationship. The wording of the questions for the two scales was the same except for verb tense (e.g., "How good will be your romantic relationship in the future?", "How much satisfied will you be with your romantic relationship in the future?"). Cronbach's alphas were .84 and .78 for the positive and romantic relationship, respectively.

Personal factors. Personal information scale comprised of a set of questions relevant to personal factors, such as age, gender, type of studies and relationship experience.

\section{Procedure}

All of the participants, first, filled in the scale of the romantic partner ideals, and, after one week, completed the rest of the scales. The students completed the scales at their departments, in quite places, in front of the researchers' co-workers, who were female and male postgraduate students and had trained for this particular part of the research by the investigator.

To match the questionnaires that were responded by the same student, students were asked to choose a code name and use it on the response sheets. The students were assured of anonymity and confidentiality.

\section{Results}

\section{Attributions for the Perceived Positive and Negative Current Romantic Relationships}

Examination of the university students' open-ended responses to the attribution scale with respect to most dominant cause of the given current romantic relationship revealed that these could be categorized into the general categories presented in Table 1. The reliability of this coding scheme was examined by asking two familiar with attribution theory judges to place each of the open-ended responses into one of the proposed categories. There was a total agreement of $87 \%$ of the re- sponses. Furthermore, self, partner, and self-partner interaction were the most prominent causes in describing the perceived as good and bad romantic relationships. Thus, Hypothesis la was confirmed.

Analysis of the frequencies of the attribution elements revealed significant effects. More accurately, the perceived good romantic relationships were mainly attributed to love (24.8\%), passion $(12.60 \%)$, effective communication $(11.00 \%)$, understanding each-other $(10.20 \%)$, and honesty-loyalty $(9.10 \%), \mathrm{x}^{2}$ $(12, \mathrm{~N}=254)=174.50, \mathrm{p}<.01$. Contrarily, the perceived bad romantic relationships were mainly attributed by the students to untrustworthiness $(15.20 \%)$, lack of passion $(13.60 \%)$, lack of honesty-loyalty $(12.10 \%)$, lack of love $(10.60 \%)$ and ineffective communication $(9.10 \%), \mathrm{x}^{2}(12, \mathrm{~N}=132)=40.20, \mathrm{p}<.01$. In addition, the participants, who estimated their romantic relationships as good, compared to participants, who perceived their romantic relationships as bad, more often mentioned communication, $x^{2}(1, N=40)=6.45, p<.05$, love, $x^{2}(1, N=$ $77)=31.18, \mathrm{p}<.01$, passion, $\mathrm{x}^{2}(1, \mathrm{~N}=50)=4.00, \mathrm{p}<.05$, understanding each-other, $\mathrm{x}^{2}(1, \mathrm{~N}=36)=7.12, \mathrm{p}<.05$, and
Table 1.

Frequency of students' attributions for their perceived good/bad romantic relationships.

\begin{tabular}{ccccc}
\hline & $\begin{array}{c}\text { Good romantic } \\
\text { relationships }\end{array}$ & \multicolumn{2}{c}{$\begin{array}{c}\text { Bad romantic } \\
\text { relationships }\end{array}$} \\
\hline Attribution elements & $\mathrm{f}$ & $\%$ & $\mathrm{f}$ & $\%$ \\
Communication & 28 & 11.00 & 12 & 9.10 \\
Love & 63 & 24.80 & 14 & 10.60 \\
Passion & 32 & 12.60 & 18 & 13.60 \\
Interest for the partner & 8 & 3.10 & 4 & 3.00 \\
Enthusiasm & 7 & 2.80 & 9 & 6.80 \\
Partner's character & 11 & 4.30 & 8 & 6.10 \\
Trustworthiness & 20 & 7.90 & 20 & 15.20 \\
Understanding each-other & 26 & 10.20 & 10 & 7.60 \\
Respect each-other & 14 & 5.50 & 4 & 3.00 \\
Honesty-loyalty & 23 & 9.10 & 16 & 12.10 \\
Anxiety & 7 & 2.80 & 5 & 3.80 \\
Geographical distance & 13 & 5.10 & 11 & 8.30 \\
Other & 2 & .80 & 1 & .80 \\
\hline
\end{tabular}

Note: The nature of attribution is positive and negative in good and bad romantic relationships, respectively.

respect each-other, $\mathrm{x}^{2}(1, \mathrm{~N}=18)=5.50, \mathrm{p}<.05$.

The findings with respect to attributional dimensions were consistent with those of attribution elements. Specifically, the results from the repeated measures MANOVA (using the Wilks's lambda estimate) with the eight attributional dimensions as within-subjects factor and the perceived romantic relationship (positive/negative) as between-subjects factor revealed significant effect of the attributional dimensions, $\mathrm{F}(7$, $378)=41.22, p<.01, \eta^{2}=.44$, significant effect of the perceived romantic relationship, $\mathrm{F}(1,384)=245.00, \mathrm{p}<.01, \eta^{2}$ $=.39$, and significant multivariate effect, $F(7,378)=23.15, p$ $<.01, \eta^{2}=.30$. The results from subsequent two repeated measures Anovas, examining differences among attributional dimensions within each group of the students' (perceived good/ bad) romantic relationships, showed significant effect in attributional dimensions in the group with the perceived good romantic relationships, $\mathrm{F}(7,242)=48.33, \mathrm{p}<.01, \eta^{2}=.59$, and in the group with the perceived bad romantic relationships, $\mathrm{F}(7$, $125)=19.40, \eta^{2}=.52$. Post hoc pairwise comparisons indicated that the students predominately attributed their good romantic relationships to locus of causality, and self-partner interactive both locus of causality and controllability, while they mainly ascribed their bad romantic relationships to partner's locus of causality and controllability, and self-partner locus of causality. The examination of the mean score and the results from subsequent Anovas, and Discriminant Function analysis (Table 2) showed that the participants made internal to themselves, personal controllable, external uncontrollable, stable, controllable by their partners, internal to their partners, internal to selfpartner and controllable in common with their partners attributions for the perceived good romantic relationships. In contrast, 


\section{G. STEPHANOU}

Table 2.

Results from discriminant analysis for the attributional dimensions for the perceived (good/bad) romantic relationships.

\begin{tabular}{|c|c|c|c|c|c|c|c|c|}
\hline \multirow[b]{2}{*}{ Attributional dimensions } & \multicolumn{2}{|c|}{ Good romantic relationships } & \multicolumn{2}{|c|}{ Bad romantic relationships } & \multirow[b]{2}{*}{ Wilks' Lambda } & \multirow[b]{2}{*}{ Discriminating power } & \multirow[b]{2}{*}{ Cohen's d } & \multirow[b]{2}{*}{$\mathrm{F}$} \\
\hline & Mean & SD & Mean & SD & & & & \\
\hline Locus of causality & 7.95 & 1.20 & 4.48 & 2.05 & .54 & .86 & 1.60 & 317.29 \\
\hline Personal controllability & 7.30 & 1.53 & 4.49 & 1.96 & .61 & .73 & 1.30 & 232.50 \\
\hline Stability & 7.32 & 1.52 & 4.47 & 2.12 & .63 & .71 & 1.21 & 219.34 \\
\hline External controllability & 4.39 & 2.61 & 4.83 & 2.12 & .99 & -- & & - \\
\hline Partner's locus of causality & 7.39 & 1.79 & 6.48 & 2.02 & .95 & -- & .40 & 19.69 \\
\hline Partner's personal controllability & 7.02 & 1.95 & 5.80 & 2.13 & .91 & -- & .53 & 36.26 \\
\hline Self-partner locus of causality & 7.88 & 1.46 & 6.32 & 1.92 & .82 & -- & .81 & 77.42 \\
\hline Self-partner controllability & 7.50 & 1.91 & 5.60 & 2.29 & .87 & -- & .87 & 55.83 \\
\hline
\end{tabular}

Note: All $\mathrm{F}(1,384)$ values are significant at the .01 level of significance; -: Non significant at the .05 level of significance; --: Attributional dimensions did not to further differentiate the one group from the other group of students.

they mainly made external to themselves, unstable, external uncontrollable, personal uncontrollable, partner's internal, partner's controllable, self-partner's internal and self-partner's controllable attributions for the perceived bad romantic relationships. Additionally, locus of causality, discriminating power $=.86$, Cohen's $\mathrm{d}=1.60$, followed by personal controllability, discriminating power $=.41$, Cohen's $\mathrm{d}=1.30$, and stability, discriminating power $=.33$, Cohen's $d=1.21$, was the most powerful factor in discriminating the one from the other group of the participants, while the rest of the attributional dimensions had no significant contribution in separating the two groups.

The above findings partly confirmed Hypotheses $1 \mathrm{~b}$ and $1 \mathrm{c}$.

\section{Effects of the Perception-Partner Ideal Discrepancies on Perceptions of the Quality of the Romantic Relationship, and on Attributions}

The results from ANOVAs revealed significant differences between the two groups of students in perception-partner ideal discrepancies. In addition, discriminant analysis, with stepwise method, was conducted to determine the set of variables that best discriminated the group of students with the perceived good romantic relationships from the group of students with the perceived bad romantic relationships. The perception-partner ideal discrepancies in attractiveness/vitality, warmth/intimacy and trustworthiness were the predictor variables, and the perceived (good/bad) romantic relationship was the grouping variable. Results confirmed the findings from ANOVAs, and, additionally, showed that trustworthiness, $F(1,384)=65.35$, $p$ $<.01$, discriminating power $=.96$, Cohen's $d=.86$, was the most powerful factor in discriminating the two groups of students, followed by warmth/intimacy, $\mathrm{F}(1,384)=61.35, \mathrm{p}<.01$, discriminating power $=.93$, Cohen's $\mathrm{d}=.80$, and attractiveness/ vitality, $\mathrm{F}(1,384)=39.81, \mathrm{p}<.01$, discriminating power $=.74$, Cohen's $d=.63$. Furthermore, examination of the mean scores showed that the students, who estimated their romantic relationships as good, compare to students, who estimated their romantic relationships as bad, had smaller perception-partner ideal discrepancies.

Also, the results from regression analysis, with the perception-partner ideal discrepancies as predictor variables and the perceived quality of the romantic relationship as predicted variable, showed that the perception-partner ideal discrepancies was a significant factor in the generation of the perception of the current quality of the romantic relationship. Specifically, the students who had smaller perception-partner ideal discrepancy, compared to students who had larger perception-partner ideal discrepancy, rated their relationships more favourable, $\mathrm{R}^{2}=.40$, $\mathrm{F}(3,382)=75.60, \mathrm{p}<.01$. However, only trustworthiness had unique effect on it, $\mathrm{b}=.44, \mathrm{t}=5.04, \mathrm{p}<.01$.

Similarly, the students' perception-partner ideal discrepancies proved to be a significant factor in the formulation of the attributions (expect for external controllability) for the perceived current quality of the romantic relationship, based on the results from a series of regression analyses with perception-partner ideal discrepancies as predictors and each of the attributional dimensions as predicted factor. More precisely, the students who had smaller perception-ideal discrepancies made more favourable attributions in personal controllability, $\mathrm{R}^{2}$ $=.09, \mathrm{~F}(3,382)=11.78, \mathrm{p}<.01$ (none attributional dimension had unique contribution), partner's locus of causality, $\mathrm{R}^{2}=.05$, $\mathrm{F}(3,382)=6.68, \mathrm{p}<.01$, trustworthiness, $\mathrm{b}=.33, \mathrm{t}=2.62, \mathrm{p}$ $<.05$, partner's controllability, $\mathrm{R}^{2}=.05, \mathrm{~F}(3,382)=5.94$ (none attributional dimension had unique contribution), self-partner interactive locus of causality, $\mathrm{R}^{2}=.07, \mathrm{~F}(3,382)=8.97, \mathrm{p}<.01$, trustworthiness, $\mathrm{b}=.28, \mathrm{t}=2.45, \mathrm{p}<.05$, self-partner interacttive controllability, $\mathrm{R}^{2}=.12, \mathrm{~F}(3,382)=15.20, \mathrm{p}<.01$ (none attributional dimension had unique contribution), and, mainly, stability, $\mathrm{R}^{2}=.15, \mathrm{~F}(3,382)=20.12, \mathrm{p}<.01$, trustworthiness, $\mathrm{b}=.30, \mathrm{t}=2.53, \mathrm{p}<.05$, and locus of causality, $\mathrm{R}^{2}$ $=.13, \mathrm{~F}(3,382)=15.80, \mathrm{p}<.01$, warmth/intimacy, $\mathrm{b}=.26, \mathrm{t}=$ $2.80, \mathrm{p}<.05$, trustworthiness, $\mathrm{b}=.24, \mathrm{t}=2.00, \mathrm{p}<.05$.

The above findings partly confirmed Hypothesis $2 \mathrm{a}$, and totally confirmed Hypothesis $2 \mathrm{~b}$.

\section{Effects of the Perception-Partner Ideal Discrepancies, Perceived Quality of Romantic Relationship and Attributions on Romantic Relationship Expectations}

The results from regression analysis indicated that the three concepts, namely perception-partner ideal discrepancies, attributions (external controllability was not entered into analysis because of lack of correlation with the other variables) and the perceived current quality of the romantic relationship, as a 
group, positively influenced the generation of expectations of the quality of the relationship in the future, explaining $44 \%$ of the variance, $\mathrm{F}(11,374)=34.73, \mathrm{p}<.01$. Furthermore, stability, $\mathrm{b}=.17, \mathrm{t}=2.73, \mathrm{p}<.05$, self-partner interactive controllability, $\mathrm{b}=.25, \mathrm{t}=3.85, \mathrm{p}<.01$, and, mainly, the perceived quality of the relationship, $\mathrm{b}=.54, \mathrm{t}=20.15, \mathrm{p}<.01$, accounted for unique variance in the expectations for the quality of the relationship in the future, suggesting that the more stable and self-partner controllable the attributions, and the more favourable the perceptions of the romantic relationship the higher the expectations for good relationship in the future. However, perception-partner ideal discrepancies in attractiveness/vitality or warmth/intimacy or trustworthiness did not uniquely contribute into relationship expectations.

Hypothesis 3 was partly confirmed by the above findings.

\section{Discussion}

This study mainly aimed at examining emerging adults' attributions for their subjectively perceived current romantic relationship as good or bad, the role of their perception-partner ideal discrepancies in evaluating and attributing causes for the same relationship, and, in turn, the effects of the three concepts on romantic relationship expectations.

The findings regarding attributions were in the main consistent with our predictions. The primary finding that the perceived good and bad romantic relationships were attributed to various causes is not surprising given that romantic relationship is important in people's life, particularly in the stage of emerging adulthood (Arnett, 2004, 2007; Fincham \& Cui, 2010; Maner \& Miler, 2010). Also, corresponding to previous research evidence (e.g., Fincham, 2003; Planalp \& Rivers, 1996; Rusbult et al., 2003), the participants stressed self-, partner-, self-partner- and situational-related factors in explaining their romantic relationships. Furthermore, by stressing intimacy-, trustworthiness-, honesty/loyalty-, and commitment-related factors in their current romantic relationships, the emerging adults confirmed previous researches about the high importance of these specific components in close relationships, and they expressed their willingness to maintain and enhance their relationships (see Barry \& Lawrence, 2008; Fehr, 2003; Fitness et al., 2005; Holmes \& Rempel, 1989; Johnson, 1991; Jones, Couch, \& Scott, 1997). Also, as previous investigations documented, particularly at the early stages of romantic love (see Dion \& Dion, 1996; Fletcher, 2002; Hatfield, 1988), the students considered love and passion as significant components of their romantic relationships. The students mentioned geographical distance as a cause for their perceived good or bad current romantic relationship. However, as Myers (1999) suggests, the critical factor is not the geographical proximity as "functional distance". Individuals, by frequent interaction, become familiar with one another and explore themselves and their potential similarities that contribute to good relationship.

The attributional pattern for the perceived good or bad romantic relationship is consistent with the above mentioned findings about happy/unhappy couples, and it is related to confirmation or non confirmation of a desirable good relationship (see Harvey et al., 2005; Herbert \& Popadiuk, 2008; Weiner, 2002, 2005). In addition, by attributing the perceived good romantic relationships to personal positive properties along with the self-partner interactive positive dispositions (love, passion, effective communication, honesty-loyalty, understanding each-other), the emerging adults boosted themselves, enhanced the possibility of being good their relationship in the future, and multiplied the longevity of their relationship (Fincham, 2003; Gottman, 1994, 1995; Harvey et al., 2005; Rusbult et al., 2003; Weiner, 2001). In contrast, by ascribing the perceived non good romantic relationships to personal uncontrollable, external, unstable, parter-self internal and partner's internal and controllable factors (untrustworthiness, lack of passion, non honesty-loyalty, lack of love, and ineffective communication), the students protected themselves and their desire for being better their relationship in the future (see Peterson \& Steen, 2005; Seligman, 2002; Stephanou, in press; Weiner, 2001). However, considering the partner as responsible for the bad relationship does not facilitate future positive relationship (Karney et al., 2003; Weiner, 1995, 2001). Furthermore, attributing the non satisfactory romantic relationship to partner's dispositional negative factors minimizes the chances of enhancing the relationship in the future (see Fletcher, 2002; Fincham et al., 1998; Planalp \& Rivers, 1996). Also, it seems that the Berscheid and Walster's (1978) concept of reciprocity of attraction involved in attributions of the self-partner internal factors, according to which people are attracted to individuals who like them and who are responsive to them. Probably, the partners were less attractive each other than they were in past.

Also, locus of causality, followed by personal controllability and stability, was the most powerful factor in discriminating the two groups of the emerging adults, while none attributional dimensions further differentiated the two groups. This specific finding probably reflects the emerging adults' tendency of self-focus in identifying themselves (see Clark \& Beck, 2010). However, research needs to clarify this speculation.

To summarize, the findings regarding the perceptions of partner ideals discrepancy were in the main consistent with our expectations, and previous researches (see Campbell \& Baumeister, 2003; Rusbult et al., 2003; Simpson et al., 2003). Specifically, the perceptions of partner ideals discrepancy had a significant effect on the evaluation of the current romantic relationship. More precisely, the emerging adults who had smaller perception-partner ideal discrepancy, compared to the emerging adults who had larger perception-partner ideal discrepancy, estimated their current romantic relationship more favourable, and used positive attributional pattern.

Apparently, the perceived good current romantic relationship had stabilized and reached relatively high levels of commitment, and, therefore, the motive of relationship enhancement and partner/relationship idealization process was powerful (see Murray et al., 1996a, 1996b; Simpson et al., 2003). On the other hand, the larger perception partner-ideals discrepancy in the perceived bad current romantic relationship seemed to motivate the emerging adults to engage in more information processing about the partner/relationship, and to use the motive of selfserving to maintain positive self-views than views of the current partner/relationship (see Simpson et al., 2003; Taylor, 1989; Weiner, 2005). The specific stage of the participants' life might be also related to this specific finding, since emerging adulthood is an age of instability during which the individuals, aiming to explore the word and clarify their identity, ask and wonder about the person they should find as a partner through life (Arnett, 2000, 2004; Fincham \& Cui, 2010). Yet, the high importance of the romantic relationship for the students may be an influential factor in it, since self-evaluation is particularly enhanced under such conditions (Tesser, 1988). 
It was also found that the perceptions of partner ideals discrepancy explained a greater amount of the variability in the perceptions of the quality of the current romantic relationship than in the subsequent attributions. This is an indication of the notion that ideals standards are more associated with self-concepts than beliefs about the relationship, and perceptions of the relationship are related to self-factors (Campbell \& Baumeister, 2003; Simpson et al., 2003). However, research needs to examine in depth this.

Interesting, the components of the perception-partner ideal discrepancy differed in the generation of the perceptions of the quality of the current romantic relationship. Specifically, the perception-partner ideal discrepancy in trustworthiness proved the critical factor in the formulation of the perceptions of the quality of the relationship, and in discriminating the group of students with the perceived good current romantic relationships from the group of students with the perceived bad good current romantic relationships. This finding is in agreement with empirical evidence showing the important role of relational trust and betrayal in romantic relationships (Jones et al., 1997). Relational trust means that the individuals have expectations that the partner is predictable and dependable, believe that they will be so in the future, and sustain relationship (Carr, 2005; Holmes \& Rempel, 1989).

Perception-partner ideal discrepancy in warmth/intimacy, closely to trustworthiness, contributed into separation of the two groups of the participants. This finding also confirmed other studies, documenting the high importance of perceiving and displaying positive types (e.g., acceptance, respect, listening, care being, interesting in partner) of social behavior in attaining and maintaining a good romantic relationship (Gottman, 1994, 1995; Rusbult, Zembrodt, \& Gunn, 1982). Furthermore, as Harvey et al. (2005) suggested, acceptance implies trustworthiness and discretion, and, probably, therefore, it had not unique effect (beyond that afforded by trustworthiness) on the generation of the estimation of the quality of the whole romantic relationship.

The perception partner ideal discrepancy in attractiveness/ vitality, in comparison to other two factors, contributed to a lower extent in separating the two groups of the students, suggesting its significant role in the early stage of forming a romantic relationship (Fitness et al., 2005).

The findings with respect to the effects of the three components of the perception partner ideal discrepancy on the attributional dimensions for the perceived quality of the current romantic relationship were similar to that of the evaluation of the relationship, and the same speculations could be applied. More precisely, trustworthiness uniquely contributed into the generation attributional dimensions of stability, and locus of causality of self, partner and self-partner, warmth/intimacy had unique and complimentarily effect on self locus of causality, while attractiveness/vitality had no effect. It is interesting that the perception-partner ideal discrepancy in trustworthiness influenced personal/relationship dispositional attributes, suggesting its crucial role in relationship development and stability, and in partners' happiness, self-esteem and identity (Campbell \& Baumeister, 2003; Simpson et al., 2003). Further, idealization of the relationship/partner is associated to a more satisfying relationship and to robust self-view (Murray et al., 1996a, 1996b).

The results from the present study also, confirming in the main our predictions and other findings (see Berscheid \& Am- mazzalorso, 2003; Fincham, 2003; Karney et al., 2003; Stephanou \& Kyridis, 2011; Trope \& Gaunt, 2005; Weiner, 2002), showed that the expectations the participants hold about their romantic relationships were partly constructed through the cognitive appraisals they made. The more stable the attributions the higher the relationship expectations, in agreement with Weiner's (2002, 2005) model. The positive effect of the self-friend interactive controllability on expectations is another indication of the significant role of the sense of "being together" in relationship development and enhancement.

The fact that the intuitive appraisal of the romantic relationship was the most powerful formulator of relationship expectations is not a surprise since the literature appears to be consistent about the importance of the evaluation of the relationship in its development (Fletcher, 2002; Harvey et al., 2005). Besides as the romantic relationship develops, the partners are forming expectations for the partner dispositional behaviour and the content of the relationship (Berscheid \& Ammazzalorso, 2003; Fincham, 2003). The participants in the present study had already formed an impression about their current romantic relationship since the duration of it ranged from six months to three and half years.

However, contrarily to our hypothesis, perception-partner ideal discrepancies in attractiveness/vitality or warmth/intimacy or trustworthiness did not uniquely contribute into romantic relationship expectations. Probably, perception-partner ideal discrepancies influenced the relationship expectations indirectly through the cognitive appraisals of the relationship. Research needs to clarify this finding, taking into consideration self-factors and relational experience.

\section{Implication of the Findings into Emerging Adulthood and Future Research}

Good romantic relationship proved important for the emerging adults. Emerging adults should be helped develop the capacity to make and maintain stable and satisfying romantic relationships. This capacity is partly acquired through attributional retraining programs (Seligman, 1998, 2005).

The findings from the present study indicate that identifying the content and the effects of partner ideals on attributing causes and forming expectations help to understand romantic relationships in emerging adulthood. However, examining self-, partner- and relationship-ideals in association to perceived causes and 'success' of relationship is more helpful in it. Research also needs to investigate the role of self-factors, such as relationship self-relevant self-esteem, self-efficacy and selfperceived mate value, and relational experience in the observed associations. Yet, research should be expanded to general population, beyond the university students. Finally, the dyad-level (both partners) process and effects on relationship are needed to be investigated.

\section{REFERENCES}

Adams, B. (1986). The family: A sociological interpretation. San Diego: Harcourt Bra.

Argyle, M. (2001). Social relationships. In M. Hewstone, W. Stroebe, J. P. Codol, \& G. M. Stepheson (Eds.), Introduction to social psychology (pp. 222-245). Oxford: Blackwell.

Arnett, J. J. (2000). Emerging adulthood: A theory of development from the late teens through the twenties. American Psychologist, 55, 469-480. doi:10.1037/0003-066X.55.5.469 
Arnett, J. J. (2004). Emerging adulthood: The winding road from the late teens through the twenties. New York: Oxford University Press.

Arnett, J. J. (2007). Emerging adulthood: What it is, and what is it good for. Child Development Perspectives, 1, 68-73. doi:10.1111/j.1750-8606.2007.00016.x

Barry, R. A., Lawrence, E., \& Langer, A. (2008). Conceptualization and assessment of disengagement in romantic relationships. Personal Relationships, 15, 297-315. doi:10.1111/j.1475-6811.2008.00200.x

Berscheid, E, \& Ammazzalorso, H. (2003). Emotional experience in close relationships. In G. J. O. Fletcher, \& M. S. Clark (Eds.), Handbook of social psychology: Interpersonal processes (pp. 308330). Oxford: Blackwell.

Berscheid, E., \& Walster, E. (1978). Interpersoal attraction. Reading, MA: Addison-Wesley.

Blascovich, J., \& Mandes, W. B. (2000). Challenge and threat appraisals: The role of affective cues. In J. P. Forgas (Ed.), Feeling and thinking: The role of affect in social cognition (pp. 131-152). New York: Cambridge University Press.

Bradbury, T. N., \& Fincham, F. D. (1990). Attributions in marriage: Review and critique. Psychological Bulletin, 107, 3-33. doi:10.1037/0033-2909.107.1.3

Buss, D. M., \& Schmit, D. P. (1993). Sexual strategies theory: A contextual evolutionary analysis of human mating. Psychological Review, 100, 204-232. doi:10.1037/0033-295X.100.2.204

Campbell, L. J., Simpson, J. A., \& Orina, M. (1999). Sex and mating: Sexual strategies, trade-offs, and strategic pluralism. In D. H. Rosen, \& M. Luebbert (Eds.), Evolution of the psyche (pp. 34-61). Westport, CT: Greenwood.

Campbell, W. K., \& Baumeister, R. F. (2003). Is loving the self necessary for loving another? An examination of identity and intimacy. In G. J. O. Fletcher, \& M. S. Clark (Eds.), Handbook of social psychology: Interpersonal processes (pp. 437-456). Oxford: Blackwell.

Carr, A. (2000). Family therapy: Concepts, process and practice. Chichester: Wiley.

Carr, A. (2005). Positive psychology. London: Routledge.

Clark, M. S., \& Beck, L. A. (2010). Initiating and evaluating close relationships: A task central to emerging adults. In F. D. Fincham, \& M. Cui (Eds.), Romantic relationships in emerging adulthood (pp. 190-212). Florida: Cambridge.

Clark, M. S., Fitness, J., \& Brissette, I. (2003). Understanding people's perceptions of relationships is crucial to understanding their emotional lives. In G. J. O. Fletcher, \& M. S. Clark (Eds.), Handbook of social psychology: Interpersonal processes (pp. 253-278). Oxford: Blackwell.

Cohen, J. (1992). A power primer. Psychological Bulletin, 112, 155159. doi:10.1037/0033-2909.112.1.155

Collins, N. L., Ford, M. B., Guichard, A. C., \& Allard, L. M. (2006). Working models of attachment and attribution processes in intimate relationships. Personality and Social Psychology Bulletin, 32, 201219. doi: $10.1177 / 0146167205280907$

Collins, W. A., \& Sroufe, A. (1999). Capacity for intimate relationships: A developmental construction. In W. Furman, B. Brown, \& C. Feiring (Eds.), The development of romantic relationships in adolescence (pp. 125-147). Cambridge: Cambridge University Press.

Connelly, J., \& McIsaac, C. (2009). Adolescents' explanations for romantic dissolutions: A developmental perspective. Journal of Adolescence, 32, 1209-1223. doi:10.1016/j.adolescence.2009.01.006

Dion, K. K., \& Dion, D. L. (1996). Toward understanding love. Personal Relationships, 3, 1-13. doi:10.1111/j.1475-6811.1996.tb00100.x

Erber, R., \& Gilmour, R. (1995). Theoretical frameworks for personal relationships. Hillsdale, NJ: Lawrence Erlbaum.

Fehr, B. (1999). "Laypersons" perceptions of commitment. Journal of Personality and Social Psychology, 79, 90-103. doi:10.1037/0022-3514.76.1.90

Fehr, B. (2003). The status of theory and research on love and commitment. In G. J. O. Fletcher, \& M. S. Clark (Eds.), Handbook of social psychology: Interpersonal processes (pp. 331-355). Oxford: Blackwell.

Fiedler, K., Semin, G. R., Finkenauer, D., \& Berkel, I. (1995). Actor- observer bias in close relationships. Personality and Social Psychology Bulletin, 21, 525-538. doi:10.1177/0146167295215010

Field, T., Diego, M., Pelaez, M., Deeds, O., \& Delgado, J. (2010). Breakup distress and loss of intimacy in university students. Psychology, 1, 173-177. doi:10.4236/psych.2010.13023

Fincham, F. D. (2003). Attributions in close relationships: From Balkanization to integration. In G. J. O. Fletcher, \& M. S. Clark (Eds.), Handbook of social psychology: Interpersonal processes (pp. 3-31). Oxford: Blackwell.

Fincham, F. D., Beach, S. R., Arias, I., \& Brody, G. (1998). Children's attributions in the family: The children's relationship attribution measure. Journal of Family Psychology, 12, 481-493. doi:10.1037/0893-3200.12.4.481

Fincham, F. D., \& Cui, M. (2010). Emerging adulthood and romantic relationships: An introduction. In D. Fincham, \& M. Cui (Eds.), Romantic relationships in emerging adulthood (pp. 3-12). Florida: Cambridge.

Fincham, F. D., Harold, G., \& Gano-Phillips, S. (2000). The longitudinal associations between attributions and marital satisfaction: Direction of effects and the role of efficacy expectations. Journal of Family Psychology, 14, 267-285. doi:10.1037/0893-3200.14.2.267

Fitness, J., Fletcher, G. J. O., \& Overall, N. (2005). Interpersonal attraction and intimate relationships. In M. A. Hogg, \& J. Cooper (Eds.), Handbook of social psychology (pp. 258-278). London: Sage.

Fletcher, G. J. O. (2002). The new science of intimate relationships. Oxford: Basil Blackwell. doi:10.1002/9780470773390

Fletcher, G. J. O., \& Fincham, F. D. (1991). Attribution process in close relationships. In G. J. O. Fletcher, \& F. D. Fincham (Eds.), Cognition in close relationships (pp. 7-35). Hillsdate, NJ: Erlbaum.

Fletcher, G. J. O., Fitness, J., \& Blampied, N. M. (1990). The link between attributions and happiness in close relationships: The role of depression and explanatory style. Journal of Social and Clinical Psychology, 9, 243-255. doi:10.1521/jscp.1990.9.2.243

Fletcher, G. J. O., \& Kininmonth, L. (1992). Interaction in close relationshipsand social cognition. In G. J. O. Fletcher, \& F. D. Fincham (Eds.), Cognition in close relationships (pp. 7235-256). Hillsdate, NJ: Erlbaum.

Fletcher, G. J. O., Simpson, J. A., Thomas, G., \& Giles, L. (1999). Ideals in intimate relationships. Journal of Personality and Social Psychology, 76, 72-89. doi:10.1037/0022-3514.76.1.72

Fletcher, G. J. O., \& Thomas, G. (1996). Close relationship lay theories: Their structure and function. In G. J. O. Fletcher, \& J. Fitness (Eds.), Knowledge structures in close relationships: A social psychological approach (pp. 3-24). Mahwah, NJ: Lawrence Erlbaum.

Fletcher, G. J. O., \& Thomas, G. (2000). Behavior and on-line cognition in marital interaction. Personal Relationships, 7, 111-130. doi:10.1111/j.1475-6811.2000.tb00007.x

Forgas, J. P., \& Smith, C. A. (2005). Affect and emotion. In M. A. Hogg, \& J. Cooper (Eds.), Handbook of social psychology (pp. 161189). London: Sage.

Gangestad, S. W., \& Simpson, J. A. (2000). The evolution of human mating: Trade-offs and strategic pluralism. Behavioral and Brain Science, 23, 573. doi:10.1017/S0140525X0000337X

Gilbert, D. T., \& Malone, P. S. (1995). The correspondence bias: The what, when, how and why of unwarranted dispositional inference. Psychological Bulletin, 111, 21-38. doi:10.1037/0033-2909.117.1.21

Gottman, J. (1993). The roles of conflict engagement, escalation and avoidance in marital interaction: A longitudinal view of five types of couples. Journal of Consulting and Clinical Psychology, 61, 6-15. doi:10.1037/0022-006X.61.1.6

Gottman, J. M. (1994). What predicts divorce. Hillsdate, NJ: Erlbaum.

Gottman, J. M. (1995). Why marriages succeed or fail. New York: Fireside.

Greitemeyer, T., \& Weiner, B. (2003). Asymmetrical attributions for approach versus avoidance behavior. Personality and Social Psychology Bulletin, 29, 1371-1382. doi:10.1177/0146167203255766

Harvey, J. H. (1987). Attributions in close relationships: Research and theoretical development. Journal of Social and Clinical Psychology, 5, 8-20. doi:10.1521/jscp.1987.5.1.8

Harvey, J. H., \& Omarzu, J. (1999). Minding the close relationship. 
Personality and Social Psychology Review, 1, 223-239.

Harvey, J., Pauwels, B., \& Zickmund, S. (2005). Relationship connections: The role of minding in the enhancement of closeness. In C. R. Snyder, \& S. Lopez (Eds.), Handbook of positive psychology (pp. 423-434). Oxford: University Press.

Hassebrauck, M. (1997). Cognitions of relationship quality: A prototype analysis of their structure and consequences. Personal Relationships, 4, 163-185. doi:10.1111/j.1475-6811.1997.tb00137.x

Hatfield, E. (1988). Passionate and compassionate love. In R. Stenberg, \& M. Barnes (Eds.), The psychology of love (pp. 191-217). New Haven, CT: Yale University press.

Hendrick, S., \& Hendrick, C. (2005). Love. In C. R. Snyder, \& S. Lopez (Eds.), Handbook of positive psychology (pp. 472-484). Oxford: University Press.

Herbert, S., \& Popadiuk, N. (2008). University students' experiences of nonmarital breakups: A grounded theory. Journal of College Student Development, 49, 1-14. doi:10.1353/csd.2008.0008

Hewstone, M., \& Antaki, M. (2001). Attribution theory and social explanations. In M. Hewstone, W. Stroebe, J. P. Codol, \& G. M. Stepheson (Eds.), Introduction to social psychology (pp. 111-141). Oxford: Basil Blackwell.

Higgins, E. T. (1987). Self-discrepancy: A theory relating self and affect. Psychological Review, 94, 319-340. doi:10.1037/0033-295X.94.3.319

Higgins, E. T. (1989). Self-discrepancy theory: What patterns of selfbeliefs cause people to suffer? In L. berkowitz (Ed.), Advance in experimental social psychology (pp. 93-136). New York: Academic Press.

Holmes, J. G., \& Rempel, J. K. (1989). Trust in close relationships. In C. Hendrick (Ed.), Review of personality and social psychology (pp. 187-220). London: Sage.

Johnson, M. P. (1991). Commitment to personal relationships. In W. H. Jones, \& D. W. Pelman (Eds.), Advance in personal relationships (pp. 117-143). London: Jessika Kingsley.

Jones, W., Couch, L., \& Scott, S. (1997). Trust and betrayal: The psychology of getting along and getting ahead. In R. Hogan, J. Johnson, \& S. Briggs (Eds.), Handbook of personality psychology (pp. 466-485). New York: Academic Press.

Karney, B. R., McNulty, J. K., \& Bradbury, T. N. (2003). Cognition and the development of close relationships. In G. J. O. Fletcher, \& M. S. Clark (Eds.), Handbook of social psychology: Interpersonal processes (pp. 32-59). Oxford: Blackwell.

Kenrick, D. T., Groth, G. E., Trost, M. R., \& Sadalla, E. K. (1993). Intergrating evolutionary and social exchange perspective on relationships: Effects of gender, self-appraisal, and involvement level on mate selection. Journal Personality and Social Psychology, 64, 951-969. doi:10.1037/0022-3514.64.6.951

Leary, M. R. (2000). Affect, cognition and the social emotions. In J. P. Forgas (Ed.), Feeling and thinking: The role of affect in social cognition (pp. 331-356). Cambridge: University Press.

Maner, J. K., \& Miler, S. L. (2010). The evolution of romantic relationships: Adaptive challenges and relationship cognition in emerging adulthood. In F. D. Fincham, \& M. Cui (Eds.), Romantic relationships in emerging adulthood (pp. 169-189). Florida: Cambridge.

McAuley, E., Duncan, T. E., \& Russell, D. W. (1992). Measuring causal attributions: The revised Causal Dimension Scale (CDSII). Personality and Social Psychology Bulletin, 18, 566-573. doi:10.1177/0146167292185006

Murray, S. L., Holmes, J. G., \& Griffin, D. W. (1996a). The benefit of positive illusions and the construction of satisfaction in close relationships. Journal of Personality and Social Psychology, 70, 79-98. doi: $10.1037 / 0022-3514.70 .1 .79$

Murray, S. L., Holmes, J. G., \& Griffin, D. W. (1996b). The self-fulfilling nature of positive illusions in romantic relationships. Love is not blind, but prescient. Journal of Personality and Social Psychology, 71, 1155-1180. doi:10.1037/0022-3514.71.6.1155

Myers, D. (1999). Social psychology. New York: McGraw-Hill.

Peterson, C., \& Steen, T. A. (2005). Optimistic explanatory style. In C. R. Snyder, \& S. J. Lopez (Eds.), Handbook of positive psychology (pp. 244-256). Oxford: University Press.
Planalp, S., \& Rivers, M. (1996). Changes in knowledge of personal relationships. In G. J. O. Fletcher, \& J. Fitness (Eds.), Knowledge structures in close relationships: A social psychological approach (pp. 299-324). Mahwah, NJ: Lawrence Erlbaum.

Prager, K. J. (1995). The psychology of intimacy. New York: Guilford.

Reis, H. T., \& Patrick, B. C. (1996). Attachement and intimacy: Component processes. In E. T. Higgins, \& A. Kruklanski (Eds.), Social psychology: Handbook of basic principles (pp. 523-563). New York: Guilford.

Regan, P. C. (1998). What if you can't get what you want? Willingness to compromise ideal mate selection standars as a function of sex, mate value, and relationship context. Personality and Social Psychology Bulletin, 24, 1294-1303. doi: $10.1177 / 01461672982412004$

Rusbult, C. E., Arriaga, X. B., \& Agnew, C. R. (2003). Interdependence in close relationships. In G. J. O. Fletcher, \& M. S. Clark (Eds.), Handbook of social psychology: Interpersonal processes (pp. 359387). Oxford: Blackwell.

Rusbult, C. E., Onizuka, R. K., \& Lipkus, I. (1993). What do we really want? Mental models of ideal romantic involvement explored through multidimensional scaling. Journal of Experimental Social Psychology, 29, 493-527. doi:10.1006/jesp.1993.1023

Rusbult, C. E., Zembrodt, I. M., \& Gunn, L. K. (1982). Exit, voice, loyalty, and neglect: Responses to dissatisfaction in romantic involvement. Journal of Personality and Social Psychology, 43, 12301242. doi:10.1037/0022-3514.43.6.1230

Schumm, W. R., Paff-Bergen, L. A., Hatch, R. C., Obiorah, F. C., Copeland, J. M., Meens, L. D., \& Bagaighis, M. A. (1986). Concurrent and discriminant validity of the Kansas marital satisfaction scale. Journal of Marriage and the Family, 48, 381-387. doi: $10.2307 / 352405$

Seligman, M. E. P. (1998). Learned optimism: How to change your mind and your life. New York: Pocket Books.

Seligman, M. E. P. (2002). Authentic happiness: Using the new positive psychology to realise your potential for lasting fulfilment. New York: Free Press.

Seligman, M. E. P. (2005). Positive psychology, positive prevention, and positive therapy. In C. R. Snyder, \& S. J. Lopez (Eds.), Handbook of positive psychology (pp. 3-9). Oxford: University Press.

Shaver, P. R., Morgan, H. J., \& Wu, S. (1996). Is love a "basic" emotion? Personal Relationships, 3, 81-96. doi:10.1111/j.1475-6811.1996.tb00105.x

Siemer, M., Mauss, I., \& Gross, J. (2007). Same situation-different emotions: How appraisals shape our emotions. Emotion, 7, 592-600. doi:10.1037/1528-3542.7.3.592

Simpson, J. A., Fletcher, G. J. O., \& Campbell, L. (2003). The structure and function of ideal standards in close relationships. In G. J. O. Fletcher, \& M. S. Clark (Eds.), Handbook of social psychology: Interpersonal processes (pp. 86-106). Oxford: Blackwell.

Simpson, J. A., \& Gangestad, S. W. (1992). Sociosexuality and romantic partner choice. Journal of Personality, 60, 31-51. doi:10.1111/j.1467-6494.1992.tb00264.x

Simpson, J. A., \& Rhodes, V. W. (1998). Attachement theory and close relationships. New York: Guilford.

Smith, C. A., \& Lazarus, R. S. (1990). Emotions and adaptation. In L. A. Pervin (Ed.), Handbook of personality: Theory and research (pp. 609-637). New York: Guilford

Stanley, S. M., Rhoades, G. K., \& Fincham, F. D. (2010). Understanding romantic relationships among emenging adults: The significant role of cohabitation and ambiguity. In F. D. Fincham, \& M. Cui (Eds.), Romantic relationships in emerging adulthood (pp. 224-251). Florida: Cambridge.

Steele, C. M. (1988). The psychology of self-affirmation: Sustaining the integrity of the self: In L. Berkowitz (Ed.), Advances in experimental social psychology (pp. 261-302). New York: Academic Press.

Stephanou, G. (2005). Academic performance and interpersonal relationships [in Greek]. In F. Vlachos, F. Bonoti, P. Metallidou, I. Dermitzaki, \& A. Efklides (Eds.), Human behavior and learning. Scientific annals of the psychological society of northern Greece (pp. 201-228). Athens: Ellinika Grammata. 


\section{G. STEPHANOU}

Stephanou, G. (2007). Students' appraisals and emotions for interpersonal relationships with teachers. In S. Vosniadou, D. Kayser, \& A. Protopapas (Eds.), Proceedings of the European cognitive science conference (pp. 568-574). Canada: Lawrence Erlibaum Associates.

Stephanou, G. (in press). Children friendship: The role of hope in attributions, emotions and expectations. Psychology.

Stephanou, G., \& Balkamou, K. (submitted). Children's attributions and emotions for their friendships with their best friend. Psychology Research.

Stephanou, G., \& Kyridis, A. (2011). University students' partner ideals and attributions in romantic relationships. In Paper presented at the 6th international SELF conference: The centrality of SELF theory and research for enabling human potential. Quebec.

Taylor, S. E. (1989). Positive illusions: Creative self-deception and the healthy mind. New York: Basic Books.

Tesser, A. (1988). Toward a self-evaluation maintenance model of social behavior. In L. Berkowitz (Ed.), Advances in experimental social psychology (pp. 181-227). New York: Academic Press.

Trope, Y., \& Gaunt, R. (2005). Attribution and person perception. In M. A. Hogg, \& J. Cooper (Eds.), Handbook of social psychology (pp. 190-208). London: Sage.
Weiner, B. (1992). Human motivation: Metaphors, theories and research. London: Sage.

Weiner, B. (1995). Judgments of responsibility: A foundation for a theory of social conduct. New York: Guilford.

Weiner, B. (2001). Intrapersonal and interpersonal theories of motivation from an attributional perspective. Educational Psychology Review, 12, 1-14. doi:10.1023/A:1009017532121

Weiner, B. (2002). Social emotions and personality inferences: A scaffold for a new direction in the study of achievement motivation. In Key speech at the 8th WATM \& motivation and emotion conference, Moskow.

Weiner, B. (2005). Motivation from an attribution perspective and the social psychology of perceived competence. In A. J. Elliot, \& C. S. Dweck (Eds.), Handbook of competence and motivation (pp. 73-84). New York: Guilford.

Weiner, B. (2006). Social motivation, justice, and the moral emotions: An attributional approach. Mahwah, NJ: Erlbaum.

Ybarra, O., \& Stephan, W. G. (1999). Attributional orientation and the prediction of behavior: The attribution-prediction bias. Journal of Personality and Social Psychology, 76, 718-727. doi:10.1037/0022-3514.76.5.718 